\title{
NEW DISTRIBUTION RECORD OF CYNOPOECILINE KILLIFISH Cynopoecilus fulgens COSTA 2002 FOR THE MAMPITUBA RIVER BASIN, SOUTHERN BRAZIL
}

\author{
Roger Henrique Dalcin ${ }^{1 *} \&$ Vinícius Abilhoa ${ }^{1,2}$
}

\begin{abstract}
${ }^{1}$ Universidade Federal do Paraná, Setor de Ciências Biológicas, Programa de Pós-Graduação em Zoologia, Av. Cel. Francisco H. Santos, 100, Jardim das Américas, CEP 81531-980, Curitiba, PR, Brazil.

${ }^{2}$ Grupo de Pesquisas em Ictiofauna (GPIc), Museu de História Natural Capão da Imbuia (MHNCI), Prefeitura de Curitiba, Rua Prof. Benedito Conceição 407, Curitiba, PR, Brazil, 82810-080.

E-mails: roger_dalcin@hotmail.com (*corresponding author); vabilhoa@uol.com.br
\end{abstract}

\begin{abstract}
The natural distribution of the aplocheiloid killifish Cynopoecilus fulgens Costa 2002 is expanded here with specimens collected in the Mampituba River basin in the of Santa Catarina State, Brazil. This record expands its geographical distribution within the Atlantic Forest coastal drainages of southern Brazil.
\end{abstract}

Keywords: Aplocheilidae; Atlantic forest; Cyprinodontiformes; Neotropic; threatened species.

The Neotropical genus Cynopoecilus Regan 1912 (Cyprinodontiformes, Aplocheilidae) is a clade of internal fertilizing annual fish, member of the subfamily Cynolebiasinae (Costa et al. 2016), distributed between Santa Catarina State (Southern Brazil) and eastern Uruguay (Costa 2002, Ferrer et al. 2014, Costa et al. 2016). All species of this genus are small-sized forest-dwelling fish that inhabit temporary ponds and flooded areas formed during rainy seasons (Costa 2002, Volcan et al. 2015).

The genus Cynopoecilus is characterized by the morphological apparatus of the male's anal fin, forming an inseminating structure, and also by the unique color pattern (Costa 1995). According to Costa (2016), synapomorphies that support the monophyly of the genus are: constriction on median portion of autopalatine; autopalatine nearly straight in lateral view; teeth on second pharyngobranchial; minute accessory caudal fin cartilages; series of seven to ten small unbranched rays connected to first two developed anal-fin proximal radials to form an inseminating fan; genital opening situated in broad transverse aperture in males; iridescent color marks restricted to lateral midline of body; broad dark reddish chocolate brown to black stripe on lateral midline of body; iris yellow in both sexes.

Costa (2016) divided Cynopoecilus into two subgenus on the basis of morphological data: Poecilopanchax Costa 2016, including only Cynopoecilus notabilis Ferrer, Wingert and Malabarba 2014, a species restricted to temporary channels within dense semi-deciduous seasonal forest in Laguna dos Patos drainage, southern Brazil; and Cynopoecilus Regan 1912, including C. melanotaenia (Regan 1912), C. intimus Costa 2002, C. nigrovittatus Costa 2002, C. fulgens Costa 2002, and C. feltrini Costa, Amorim and Mattos 2016, species found between the Tubarão River basin and the Patos-Mirim lagoon system in southern Brazil and also adjacent areas of Uruguay. Costa (2016) also considered C. multipapillatus Costa 2002 as junior synonym of $C$. fulgens. 
The killifish C. fulgens has its distribution known for the coastal plains adjacent to the Patos lagoon (Figure 1), Rio Grande do Sul State (Costa 2002, Costa et al. 2016), where it occurs in temporary pools and swamps, and feeds mainly on microcrustaceans and autochthonous insects (Keppeler et al. 2013, Dias et al.2017). Herein we report new sites of occurrence of Cynopoecilus fulgens in the Mampituba River basin, increasing the known localities for this threatened killifish species.

Sampling with dip nets were conducted in June 2018 in the city of Balneário Arroio do Silva, Santa Catarina State, Southern Brazil. Sampling authorization $n^{\circ} 9784 / 2017$ was emitted by the Foundation for the Environment of the Santa Catarina State (FATMA). The study site comprises seasonal ponds and wetlands in remaining areas of Atlantic Forest Restinga formations (sandbanks) in the Mampituba River basin, heavily impacted by urban development (Figure 2).
Captured specimens were first anesthetized with eugenol solution and then fixed in $10 \%$ formalin solution for 48 hours, washed in running water and preserved in $70 \%$ ethanol. Twenty-four individuals were identified as $C$. fulgens following the diagnosis proposed by Costa (2002) (Figure 3). Voucher specimens analyzed were deposited in the ichthyological collections of the Universidade Federal do Rio de Janeiro (UFRJ) and Museu de História Natural Capão da Imbuia (MHNCI) (Table $1)$.

Morphometric measurements were made according to Costa $(1988,1995)$ using a digital caliper and recorded to the nearest $0.1 \mathrm{~mm}$, under a dissecting microscope, only for 12 specimens stored in the collection of Museu de História Natural Capão da Imbuia. Measurements were presented as percentages of standard length (SL), except for those related to head morphology, expressed as percentages of head length.

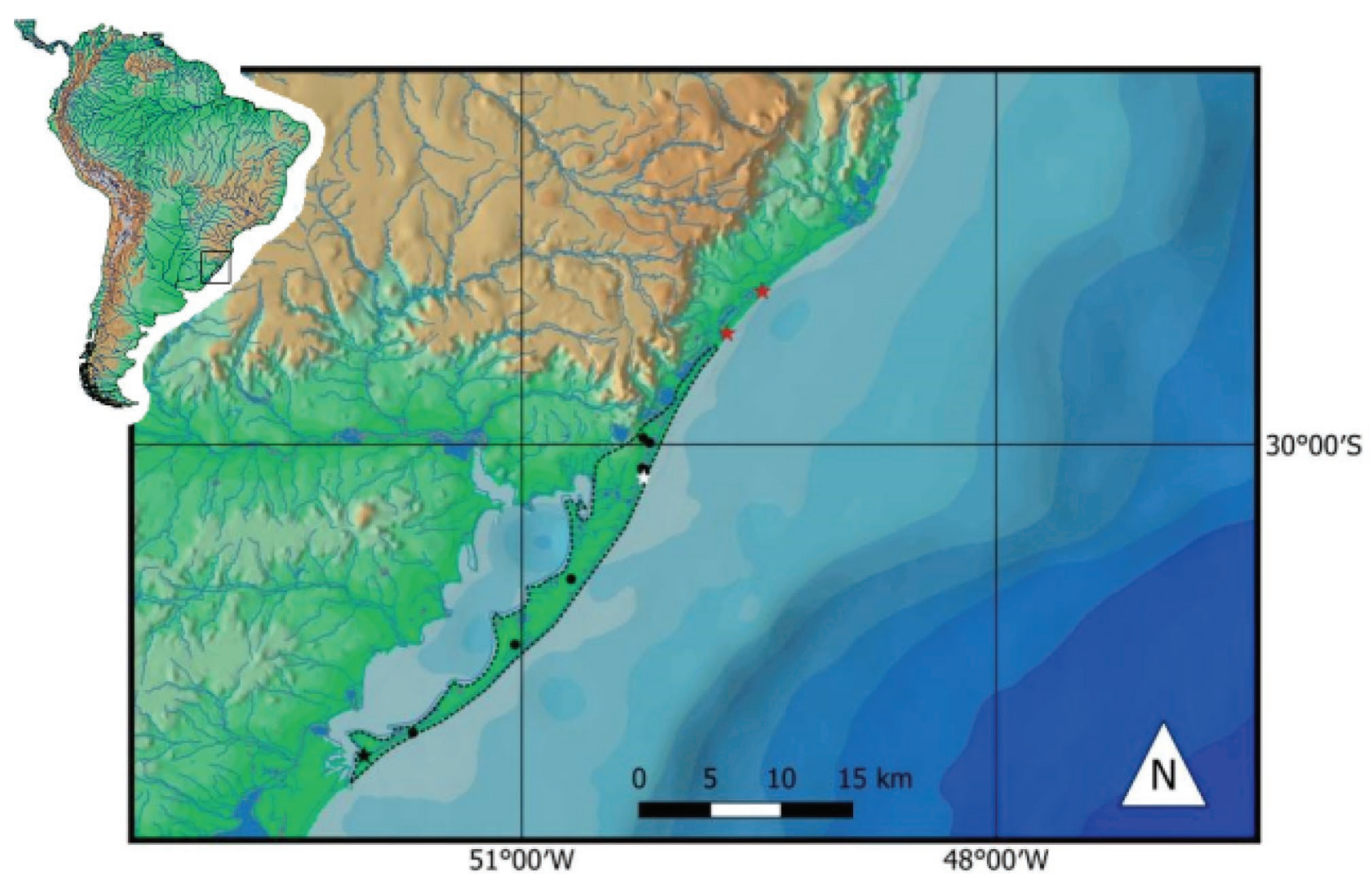

Figure 1. Geographical distribution (dashed line) of Cynopoecilus fulgens in Rio Grande do Sul State, southern Brazil (based on Costa et al. 2016). Black dots represent the material examined (collection sites) in Costa (2002) and Costa (2016). Stars represent type localities (black star = C. fulgens; white star = C. multipapillatus). Red stars represent the new records at Mampituba River basin. 


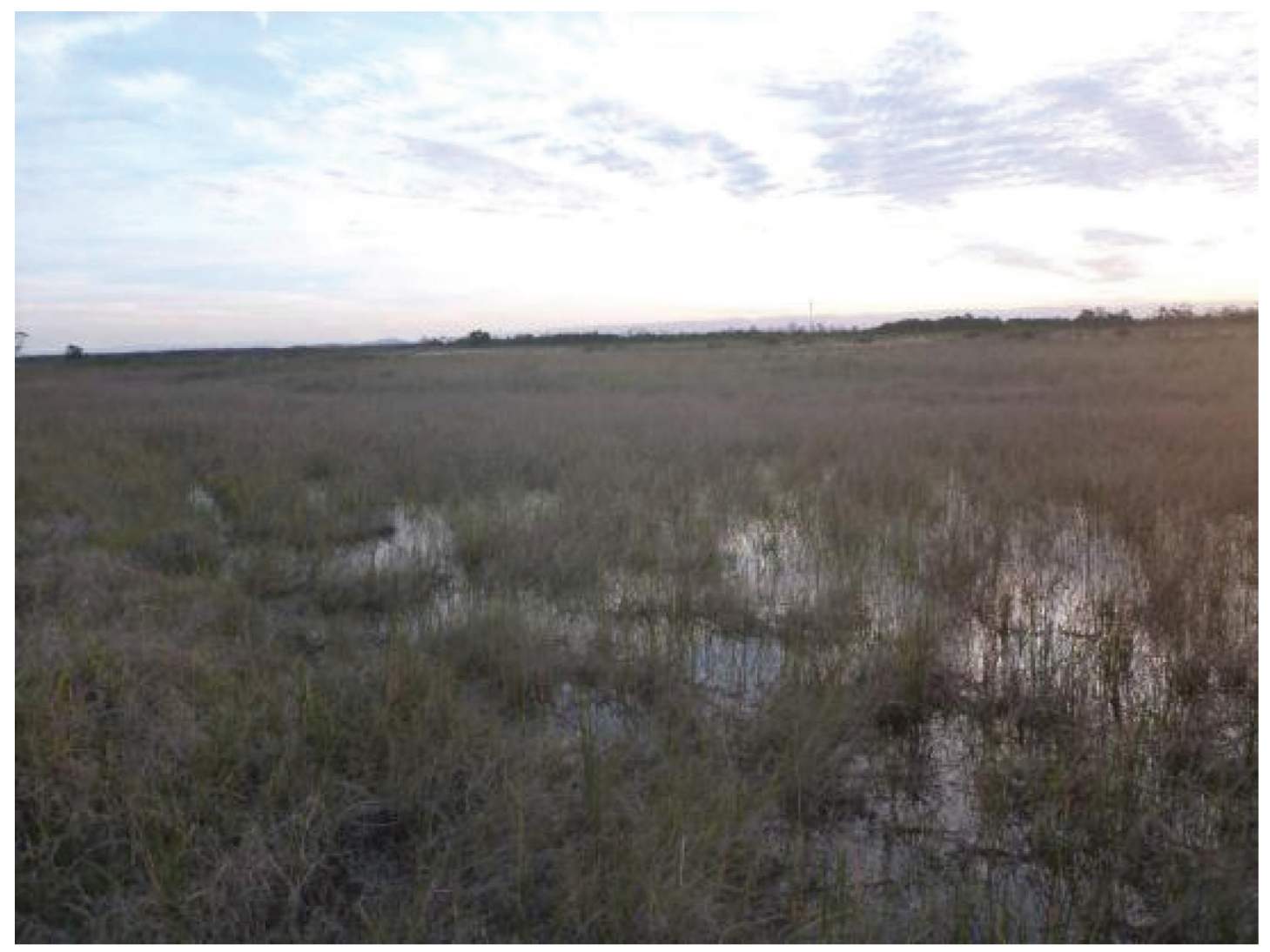

Figure 2. Aquatic biotopes (seasonal ponds and flooded areas) where Cynopoecilus fulgens was registered in the municipalities of Passos de Torres (above) and Balneário Arroio do Silva (below) in Santa Catarina State, southern Brazil.

The updated distribution map of $C$. fulgens (Figure 3) was based on data from two literature reviews on this species (Costa 2002, 2016, Costa et al.2016), information under the catalogue numbers UFRJ 11834 and 11835, the present record (UFRJ 11912, MHNCI 12694) and also with information obtained from the SpeciesLink database (CRIA 2018).

Costa (2002) distinguished C. fulgens from all other species of the group by the male's caudal fin with the presence of dark spots all along its extension, irregular dark brown marks on the back right under the male's dorsal fin, dorsal profile of the head lightly concave in adult males, dark reddish-brown lateral stripes on side of male's body, 11-15 supra-orbital neuromasts and one to three neuromasts by scale on the lateral line. In addition, $C$. fulgens can be distinguished from $C$. feltrinii by having E-scales medially separated by an interspace ( $\nu s$. E-scale medially overlapped) (Costa et al. 2016). All these features were observed in the specimens analyzed. Morphometric measurements obtained were presented on Table 2, and compared to the ones showed by Costa (2002) in the original description. Two females and one male exhibited an extreme reduction of pelvic fins length (Figure 4).

These new records expand the geographical distribution of $C$. fulgens in temporary ponds and flooded areas within the Atlantic Forest coastal drainages of southern Brazil. The threatened status of $C$. fulgens has not been assessed for the IUCN Red List, however it was included in the Brazilian

Table 1. Vouchers of Cynopoecilus fulgens obtained in the Mampituba River Basin in the Santa Catarina State, Southern Brazil.

\begin{tabular}{lll}
\hline Catalog number & \multicolumn{1}{c}{ Municipality } & Geographic coordinates \\
\hline UFRJ 11912 & Balneário Arroio do Silva & $29^{\circ} 2^{\prime} 3.35^{\prime \prime} \mathrm{S}, 49^{\circ} 28^{\prime} 47.05^{\prime} \mathrm{W}$ \\
MHNCI 12694 & Balneário Arroio do Silva & $29^{\circ} 2^{\prime} 3.35^{\prime \prime} \mathrm{S}, 49^{\circ} 28^{\prime} 47.05^{\prime} \mathrm{W}$ \\
\hline
\end{tabular}




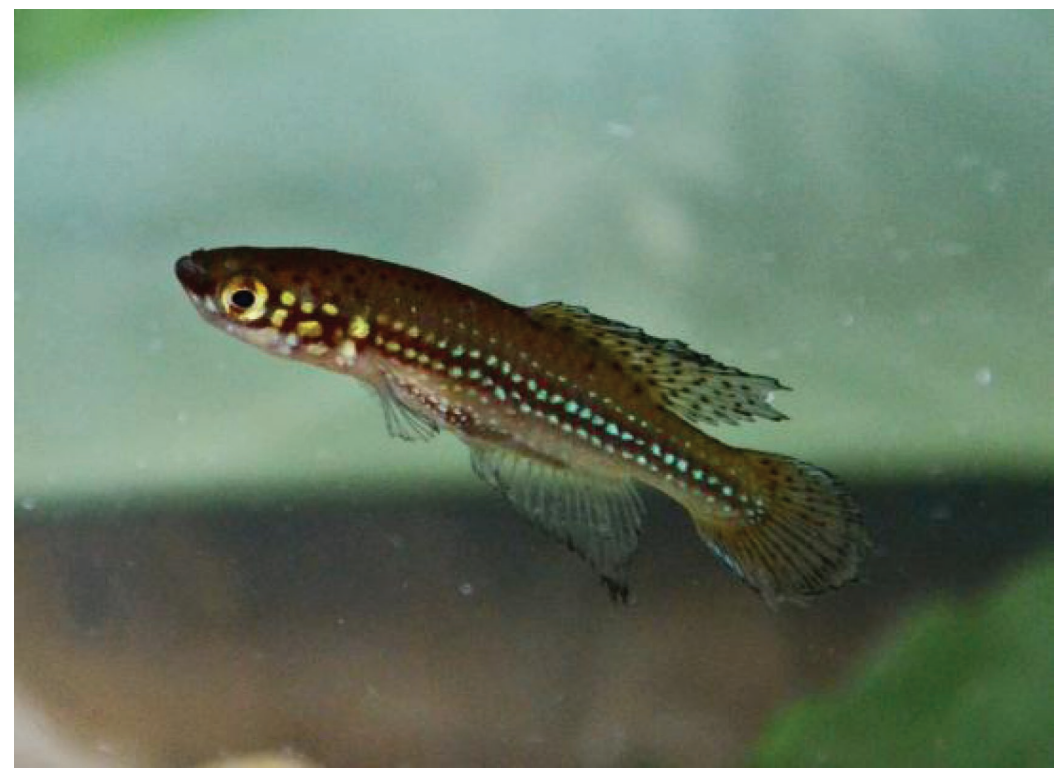

Figura 3. Male of Cynopoecilus fulgens registered in the municipality of Passo de Torres, Santa Catarina State, Southern Brasil. Photo by Caio Feltrin.

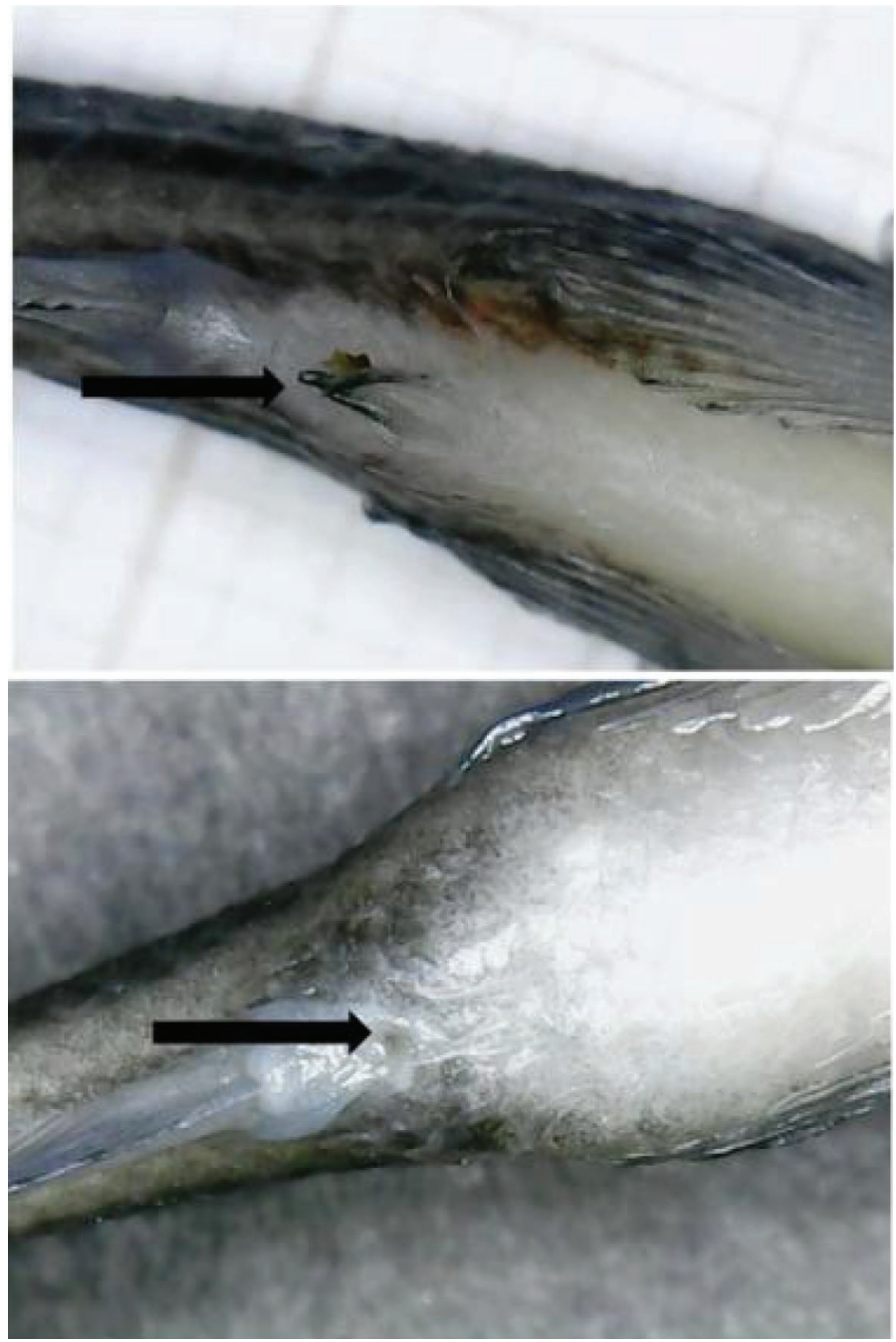

Figure 4. Ventral view of Cynopoecilus fulgens, showing the extreme reduction of pelvic fins in a male (above) and female (below) examined (MHNCI 12694). 
Table 2. Morphometric data of 12 individuals of Cynopoecilus fulgens (MHNCI 12694) obtained in the Mampituba River Basin in the Santa Catarina State, Southern Brazil.

\begin{tabular}{lcccc}
\hline & \multicolumn{4}{c}{ Range } \\
\cline { 2 - 5 } & Males & Costa (2002) & Females & Costa (2002) \\
\hline SL (mm) & $20.10-23.70$ & $30.1-38.9$ & $14.30-18.00$ & $21.3-29.3$ \\
\hline \multicolumn{4}{c}{ Percent of standard length } \\
\hline Body depth & $19.90-24.30$ & $27.5-29.5$ & $20.98-22.78$ & $29.0-27.2$ \\
Depth of caudal peduncle & $9.96-11.98$ & $12.9-15.1$ & $11.19-12.78$ & $12.6-13.6$ \\
Predorsal length & $51.74-58.72$ & $52.6-57.9$ & $53.85-61.11$ & $60.4-63.5$ \\
\hline Prepelvic length & $29.90-50.20$ & $46.7-50.6$ & 44.10 & $52.2-55.0$ \\
\hline Length of dorsal fin & $20.50-26.70$ & $28.5-30.4$ & $22.90-27.20$ & $25.2-28.3$ \\
Length of anal fin & $20.80-25.30$ & $24.6-28.7$ & $21.50-24.50$ & $20.4-21.7$ \\
Length of pelvic fin & $3.10-6.30$ & $5.6-7.0$ & 4.70 & $5.6-7.4$ \\
\hline Length of pectoral fin & $16.90-20.80$ & $16.1-18.5$ & $16.10-20.00$ & $18.2-20.3$ \\
Length of caudal fin & $19.00-25.40$ & $27.3-32.8$ & $23.10-26.70$ & $30.3-34.0$ \\
Head length & $24.70-28.40$ & $26.4-28.4$ & $24.50-28.90$ & $27.2-29.2$ \\
\hline & & Percent of head length & \\
\hline Head depth & $60,70-68,90$ & $71.9-77.1$ & $71,20-74,30$ & $70.2-78.7$ \\
\hline Head width & $57,90-64,30$ & $66.5-69.1$ & $67,30-68,60$ & $69.7-73.9$ \\
Eye diameter & $33,30-42,60$ & $31.5-33.8$ & $40,00-44,20$ & $33.1-35.9$ \\
\hline Snout length & $7,00-15,80$ & $13.1-14.2$ & $5,70-14,00$ & $12.6-14.9$ \\
\hline Lower jaw length & $17,50-31,50$ & $24.4-25.9$ & $14,30-26,90$ & $19.8-24.0$ \\
\hline
\end{tabular}

Red List of Threatened Fauna (ICMBio 2018) and it is also considered vulnerable in the list of threatened fauna of the Rio Grande do Sul State (Volcan et al. 2015). In fact, the great majority of killifish deserves particular attention with respect to their conservation status due to their high degree of endemism and the fact that several species are usually registered in non-protected areas of the Atlantic Forest coastal drainages, one of the most threatened biomes in the world (Costa 2009, 2012, Volcan et al. 2015).

\section{ACKNOWLEDGEMENTS}

We wish to thank Dr Wilson Costa (UFRJ) and Axel Katz (UFRJ) for support during the taxonomic identification of $C$. fulgens individuals. We thank Caio Feltrin for providing information and photographs. We also thank CAPES for financial support (master's degree fellowship to RD under VA's supervision).

\section{REFERENCES}

Costa, W. J. E. M. 1988. Sistemática e distribuição do complexo de espécies Cynolebias minimus (Cyprinodontiformes, Rivulidae), com a descrição de duas espécies novas. Revista Brasileira de Zoologia, 5(4), 557-570.

Costa, W. J. E. M. 1995. Revision of the Neotropical Annual Fish Genus Cynopoecilus (Cyprinodontiformes: Rivulidae). Copeia, 2, 456-465. DOI: 10.2307/1446910

Costa, W. J.E. M. 2002. The annual fish genus Cynopoecilus (Cyprinodontiformes: Rivulidae): Taxonomic revision, with descriptions of four new species. Ichthyological Explorations of Freshwaters, 13, 11-24.

Costa, W. J.E. M. 2009. Peixes aploqueilóideos da Mata Atlântica brasileira: história, diversidade e conservação/Aplocheiloid fishes of the Brazilian Atlantic Forest: history, diversity and conservation. Rio de Janeiro: Museu Nacional UFRJ: p.172. 
Costa, W. J. E. M. 2012. Delimiting priorities while biodiversity is lost: Rio's seasonal killifishes on the edge of survival. Biodiversity \& Conservation, 21(10), 2443-2452.

Costa,W.J.E. M.2016. Comparative morphology and classification of South American cynopoeciline killifishes (Cyprinodontiformes: Aplocheilidae), with notes on family-group names used for aplocheiloids. Vertebrate Zoology, 66(2), 125140.

Costa,W. J.E. M., Amorim, P. F., \& Mattos, J.L. O. 2016. A new species of inseminating seasonal killifish of the Cynopoecilus melanotaenia complex from southern Brazil (Cyprinodontiformes: Rivulidae). Biodiversity Data Journal, 4, e6888. DOI: $10.3897 / B D J .4 . e 6888$

CRIA. 2018. SpeciesLink network. Centro de Referência em Informação Ambiental. Retrieved on October 15, 2018, from http://www.splink. org.br

Dias, T. S., Stein, R. J., \& Fialho, C. B. 2017. Ontogenetic variations and feeding habits of a Neotropical annual fish from southern Brazil. Iheringia Série Zoologia, 107, e2017020. DOI: 10.1590/1678-4766e2017020

Ferrer, J., Wingert, J. M., \& Malabarba, L. R. 2014. Description of a new species and phylogenetic analysis of the subtribe Cynopoecilina, including continuous characters without discretization (Cyprinodontiformes: Rivulidae). Zoological Journal of the Linnean Society, 172(4), 846-866. DOI: 10.1111 /zoj.12190

ICMBio. 2018. Brazilian Red List of Threatened Species. Instituto Chico Mendes de Conservação da Biodiversidade. Retrieved on October 15, 2018, from http://www.icmbio.gov.br/portal/ faunabrasileira/lista-de-especies

Keppeler, F. W., Lanés, L. E. K., Rolon, A. S., Stenert, C., \& Maltchik, L. 2013. The diet of Cynopoecilus fulgens Costa (Cyprinodontiformes: Rivulidae) in Southern Brazil wetlands. Italian Journal of Zoology, 1-12. DOI: 10.1080/11250003.2012.744107

Volcan, M. V., Gonçalves, A. C., Lanés, L. E. K., \& Guadagnin, D. L. 2015. Annual Fishes (Rivulidae) from Southern Brazil: A Broad-Scale Assessment of their Diversity and Conservation. In: N. Berois, G. García, \& R. O. Sá (Eds.). Annual fishes: Life history strategy, diversity, and evolution. pp. 185-203. Boca Raton: CRC Press. 